\title{
Analysis of the Impact LEED-NC Criteria on Appraised Unit Land Value
}

\author{
Son, Kiyoung ${ }^{1}$ Kim, Gwang-Hee ${ }^{2}$ Park, Young Jun ${ }^{3}$ Kim, Sun-Kuk ${ }^{1 *}$ \\ Department of Architectural Engineering, Kyung Hee University, Yongin, 446-701, Korea ${ }^{1}$ \\ Department of Architectural Engineering, Kyonggi University, Korea ${ }^{2}$ \\ Department of Construction Engineering and Environmental Sciences, Korea Military Academy, Korea ${ }^{3}$
}

\begin{abstract}
In recent years, LEED-NC (Leadership in Energy and Environmental Design for New Construction) has become one of the most widely adopted environmental certification systems in the United States. However, according to some researchers, the adoption of the LEED-NC is perceived to add to construction cost and duration compared to conventional building standards. Therefore, it is necessary to examine the economic benefits of LEED-NC to consider how it can be applied worldwide. This study focuses on the impact of LEED-NC on the appraised unit value of parcels in San Francisco County based on the number of LEED-NC Public Transportation Access (PTA) qualified buses, light rail and commuter rail stops, distance to the closest bus, light rail and commuter rail stops, zoning class and parcel size. As a population of interest, San Francisco County was chosen since it is known as a region with well-organized transportation systems including bus, light rail and commuter rail systems. According to the correlation results, this study shows that the appraised land value is significantly affected by LEED-NC PTA, and is correlated to a higher appraised unit value of land parcels.
\end{abstract}

Keywords : leadership in energy and environmental design (LEED), green building, sustainability, public transportation, san francisco county.

\section{Introduction}

Leadership in Energy and Environmental Design (LEED) is one of the most important sustainability rating systems in the United States[1]. Since its inception in 1998, LEED has evolved to more accurately represent and incorporate emerging green building technologies[2]. LEED version 1.0 was launched in 1998, and the current revision, version 3.0, was released in 2009. Currently, LEED consists of nine rating systems, including a) LEED for New Construction and major renovations

Received : June 27, 2012

Revision received : August 27, 2012

Accepted : October 10, 2012

* Corresponding author : Kim, Sun-Kuk

[Tel: 82-31-201-2922, E-mail: kimskuk@khu.ac.kr]

(c)2012 The Korea Institute of Building Construction, All rights reserved.
(LEED-NC), b) LEED for core and shell, c) LEED for schools, d) LEED for retail, e) LEED for healthcare, f) LEED for commercial interiors, g) LEED for existing buildings, h) LEED for neighborhood development, and i) LEED for homes[2]. Of these, LEED-NC is the most widely adopted rating system. Since its launch in 2000, approximately $54 \%$ of all LEED certified projects in the United States have been certified by LEED-NC[3]. LEED-NC is designed to guide and distinguish high-performance commercial and institutional projects, including office buildings, high-rise residential buildings, government buildings, recreational facilities, manufacturing plants and laboratories. LEED-NC is now being utilized in many countries, including China, Korea, India, and Canada[4].

However, according to some researchers, using 
the LEED-NC rating system will cause a cost increase of about $\$ 2$ to $\$ 5$ per square foot for office projects [5]. Furthermore, since LEED-NC projects are complex systems, adopting LEED-NC requires an increased amount of planning and monitoring[6]. Therefore, if this study proves that the adoption of LEED-NC does not provide any economic benefit, there is a need to adjust the current rating system.

This study focuses on Public Transportation Access (PTA) criteria under the Sustainable Sites category of LEED-NC. Based on these criteria, the main objective of this study is to investigate the impact of LEED-NC PTA on land value in San Francisco County.

San Francisco County was selected for this study as a region of the US with a well-organized public transportation system. Virtually every location in the city of San Francisco lies within a 1/4 mile of a transit route of regional buses, MUNI, BART or Caltrain[7].

In this study, to achieve the objective, the correlation analysis was conducted for residential and mixed zones planned by the San Francisco planning department. A mixed zone is defined as a district featuring high-density dwellings with compatible commercial uses on the ground floor to enhance neighborhoods. First, residential and mixed zones were identified in San Francisco County. Second, based on LEED-NC PTA criteria, a LEED-NC PTA map using GIS was created to select LEED-NC PTA qualified parcels. Third, sample parcels information was collected to perform correlation analysis, then the Pearson's correlation among all variables was conducted to investigate the impact of LEED-NC PTA on land value in San Francisco County. To achieve the objective of this study, the following four research hypotheses were tested.
1) There is a significant relationship between the appraised unit value of parcels and the number of bus stops with connections to two or more bus lines within one-quarter mile walking distance (LEED-NC PTA criteria for bus stops)

2) There is a significant relationship between the appraised unit value of parcels and the number of light rail stations and commuter rail stations within one-half mile walking distance (LEED-NC PTA criteria for rail stations)

3) There is a significant relationship between the appraised unit value of parcels and zoning (residential and mixed)

4) There is a significant relationship between the appraised unit value of parcels and parcel size

As the appraised value of land in developed areas is likely to be affected by some externalities, such as already developed amenities, this study is intentionally limited to parcels from "unimproved" land in San Francisco County. The real property values consist of land plus any attached improvements. Amenities from one area may indirectly impinge on adjoining areas. As this study focuses on the appraised value of unimproved land parcels, the impact of these external factors on appraised land value can be minimized. Properties receiving tax exemption are also excluded from this study.

Furthermore, in LEED-NC PTA criteria, the distance from a main building entrance to public transit nodes is measured. But as unimproved parcels data were used in this study, buildings do not exist on the parcels. Therefore, the distance from parcel centroid to public transit nodes was measured using GIS, rather than the distance from a main building entrance. Land for public use was also not included in this study. 


\section{Literature review}

There has been diverse research on factors related to appraised land value. Researchers have examined the impact of land use such as parks and wetlands and views of water-covered areas on appraised land value[8,9,10]. In addition, there have been studies on the impact of public transit nodes in various areas on appraised land value[11,12,13]. As well, researchers have investigated the impact of the LEED-NC rating system on appraised land value in Houston. The following describes the impact of diverse variables such as land use, views, public transit nodes and the LEED-NC rating system on appraised land value.

\subsection{LEED Green Building Rating System}

LEED-NC defines the leadership position for designing and building commercial, institutional, government buildings and high-rise residential buildings of all sizes in a way that produces quantifiable benefits for occupants, the environment and their owners[2]. It has emerged as the national leader in the market transformation of the commercial sector, making a convincing value proposition for green buildings[4].

LEED-NC addresses the environmental impacts of site and materials selection, demolition, and construction. Since it was launched in 2000, over 4,000 building projects in the US have been certified as LEED-NC[4]. The primary goal of LEED-NC is to promote healthy, durable, affordable, and environmentally sound practices in building design and construction[2].

As shown in Figure 1, LEED-NC addresses seven categories, including sustainable sites, water efficiency, energy and atmosphere, materials and resources, indoor environmental quality, innovation in design, and regional priority. Of these, this study focuses on the Credit 4. Alternative Transportation under the Sustainable Sites category.

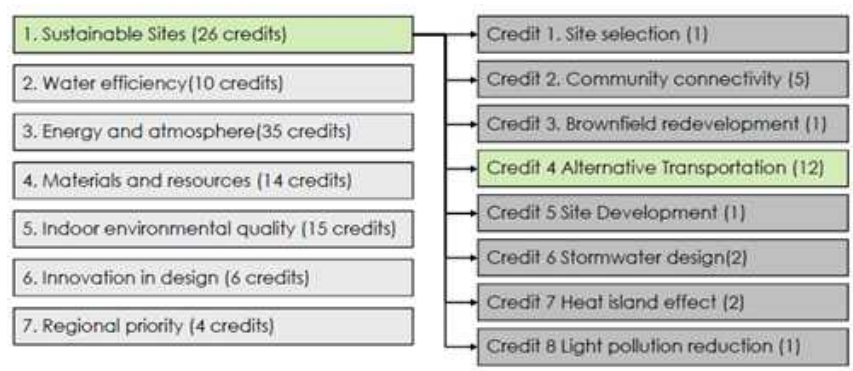

Figure 1. The seven categories of LEED-NC, and the 8 credits under the Sustainable Sites category

\subsection{The Impact of Land Use on Appraised Land Value}

Urban parks and forests, water resorts, lake shores, farmlands and land use affect residential zones because these provide opportunities for recreation, relief from urban stresses and congestion[10]. Benson et al. have investigated how views from homes affect the land value in residential areas[14]. Geoghegan investigated the value of open spaces in residential land use[15]. Irwin also concluded that open spaces within $1 \mathrm{~km}$ positively affect residential property value[16]. Seiler et al. investigated the impact of lake views on residential property values[17].

According to the study of Baranzini and Schaerer, parks significantly affect residential rent in Geneva, Switzerland. In particular, the size and view of the natural environment increased residential rents, while developed environmental views negatively affected rents. The researchers concluded that residential rents in Geneva increased by $57 \%$ when there was a view of water-covered areas, while the surface of agricultural areas in the neighborhood of the building and industrial areas did not have a 
significant impact on residential rents[10].

Lutzenhiser and Netusil investigated the impact of parks on housing prices in Portland, Oregon. The researchers concluded that housing prices near parks are more expensive, with prices increasing based on park size[8]. Yu et al. also measured the impact of a view of the sea on real estate prices[18].

Therefore, although many researchers have investigated factors related to appraised land value, no research has been conducted on the impact of LEED-NC PTA criteria on appraised land value in San Francisco County.

\subsection{The Impact of Public Transit Nodes on Appraised Land}

\section{Value}

Cervero and Duncan studied the impact of public transit such as commuter rail, light rail, and bus rapid transit on appraised land value in Los Angeles County. The data were divided into four groups such as single, multi-family housing, condominiums, and commercial buildings. The land value of approximately 30\% of the parcels within 0.5 miles of public transit was examined[11]. Figure 2 shows the results of the study, which present the effects of proximity of bus, light rail, commuter rail transit on commercial land value.

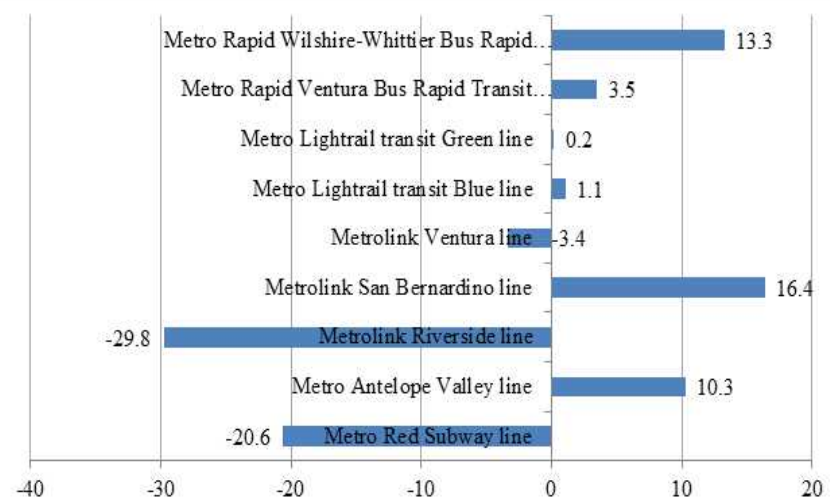

Figure 2. Commercial land value premiums or discounts in Los Angeles County based on proximity to public transit lines
In addition, a survey of the existing literature shows that while there have been many studies examining the impact of transit stations on appraised land value[11,12,13], no research has been conducted to determine the extent to which LEED-NC PTA components might further affect land values, as shown in Table 1.

Therefore, although much research has been conducted that investigates the impact of transit nodes on the appraised unit value of parcels[11,12,13], no research has been conducted regarding the relationship between the LEED-NC PTA criteria and the appraised unit value of parcels in San Francisco County.

Table 1. Existing literature

\begin{tabular}{|c|c|c|c|c|}
\hline Type & $\begin{array}{l}\text { Author } \\
\text { (year) }\end{array}$ & Impact & $\begin{array}{c}\text { Location } \\
\text { (Transit facility) }\end{array}$ & $\begin{array}{l}\text { Criteria } \\
\text { (within) }\end{array}$ \\
\hline Heavy rail & $\begin{array}{c}\text { Landis et al } \\
\text { (1994) }\end{array}$ & $\begin{array}{c}\text { Negativ } \\
e\end{array}$ & $\begin{array}{c}\text { San Mateo } \\
\text { County } \\
\text { (CalTrain) }\end{array}$ & $\begin{array}{l}\text { Single-family } \\
\text { (500 feet) }\end{array}$ \\
\hline Light rail & $\begin{array}{c}\text { Landis et al } \\
\text { (1994) }\end{array}$ & $\begin{array}{c}\text { Negativ } \\
\mathrm{e}\end{array}$ & $\begin{array}{l}\text { San Jose } \\
\text { (Light rail) }\end{array}$ & $\begin{array}{l}\text { Single-family } \\
\text { (500 feet) }\end{array}$ \\
\hline Bus & $\begin{array}{l}\text { Cervero and } \\
\text { Duncan } \\
\text { (2004) }\end{array}$ & $\begin{array}{l}\text { Negativ } \\
e\end{array}$ & $\begin{array}{c}\text { Los Angeles, } \\
\text { California } \\
\text { (Bus Rapid } \\
\text { Transit Red Line) }\end{array}$ & $\begin{array}{l}\text { Housing price } \\
\text { (one-half mile) }\end{array}$ \\
\hline Heavy rail & $\begin{array}{l}\text { McMillen } \\
\text { and } \\
\text { McDonald } \\
\text { (2004) }\end{array}$ & Positive & $\begin{array}{l}\text { Chicago, Illinois } \\
\text { (The Midway } \\
\text { Rapid } \\
\text { Transit Line) }\end{array}$ & $\begin{array}{l}\text { Housing price } \\
\text { (one block) }\end{array}$ \\
\hline Light rail & $\begin{array}{l}\text { Cervero and } \\
\text { Duncan } \\
\text { (2004) }\end{array}$ & Positive & $\begin{array}{l}\text { Los Angeles, } \\
\text { California } \\
\text { (Metrolink) }\end{array}$ & $\begin{array}{l}\text { Housing price } \\
\text { (one-half mile) }\end{array}$ \\
\hline Bus & $\begin{array}{l}\text { Cervero and } \\
\text { Duncan } \\
\text { (2004) }\end{array}$ & Positive & $\begin{array}{c}\text { Los Angeles, } \\
\text { California } \\
\text { (Bus Rapid } \\
\text { Transit Blue Line) }\end{array}$ & $\begin{array}{l}\text { Condominium } \\
\text { (one-half mile) }\end{array}$ \\
\hline
\end{tabular}

\subsection{The Impact of the LEED Rating System on Appraised Land Value}

Park conducted a study to identify the relationship between LEED-NC criteria (i.e.: site selection, brownfield, and public transportation access) and the appraised unit value of parcels in Houston. In the study, the LEED-NC PTA criteria were found to be significant factors associated 
with an increase in the appraised unit value of parcels within Houston[19].

As an extension of Park's research, Joshi's study quantified the impact of LEED-NC PTA criteria components on the appraised unit value of parcels in Houston using a multiple linear regression. The regression model was established to predict the appraised unit value of parcels in Houston. The dependent variable was the appraised unit value of parcels $(\$ / \mathrm{sf})$, while the independent variables are the number of bus stops and the number of light rail stations that meet LEED-NC criteria and the area of given parcels.

Joshi first collected data for sample parcels in Houston from the Harris County Appraisal District website, then analyzed the data through statistical methods, including correlation and multiple regression analysis, to predict the appraised unit value of these parcels. Equation (1) represents the developed regression model.

Predicted appraised unit value of land in Houston $=[1.873-0.015$ (Num Bus Stops) +0.426 (Num Rail Stations) - 0.000002522 (area) $\rfloor^{(1 / 0.3)}$

$$
\text { Equation ------ (1) }
$$

According to the results, an increase in the number of light rail stations led to an increase in the appraised unit value of a parcel, while the number of LEED-NC qualified bus stops negatively affected the appraised unit value of parcels in Houston[20].

As Houston has no commuter rail stations, Joshi's study focused only on the number of bus stops and light rail stations[20]. To address this issue, this study focuses on whether or not the PTA, including bus, light rail and commuter rail systems, as part of the LEED-NC rating system, affects the appraised unit value of parcels.

\subsection{Market Value vs. Appraised Value of Land}

Both market value and appraised value are used in the dealings of land, residential homes, commercial property, retail buildings, and farms. However, there are differences between market value and appraised value. Market value is consumer-driven, while appraised value is determined by experts[21].

Appraised values are based on gathered data and the judgment of the professionals conducting the appraisal. The market value has more variance than the appraised value. Unlike the appraised value, buyers influence the market value of a property, because a property is only worth what a buyer is willing to pay[21].

An appraiser establishes the appraised value based on recent property sales in the neighborhood, the condition of the land and a number of other details such as its features and functionality, while market value can be determined by licensed or unlicensed individuals. For most purposes, the appraised value overrides the market value[22].

If the market value is calculated by a licensed real estate agent, the report includes active property listings, pending property sales, properties sold in the last 12 months and expired listings[23]. But appraised value is determined by an appraiser. Appraisers do not represent an individual's interests regarding a property[23].

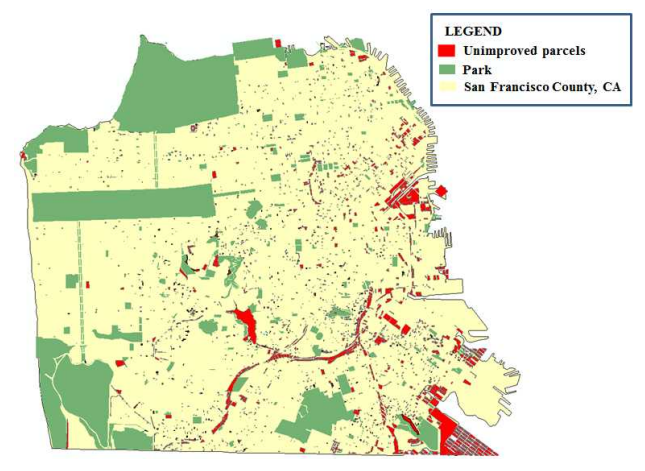

Figure 3. Selected sample parcels 


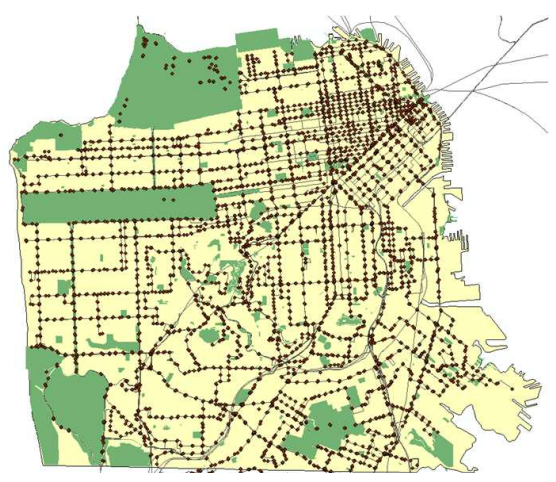

(a)

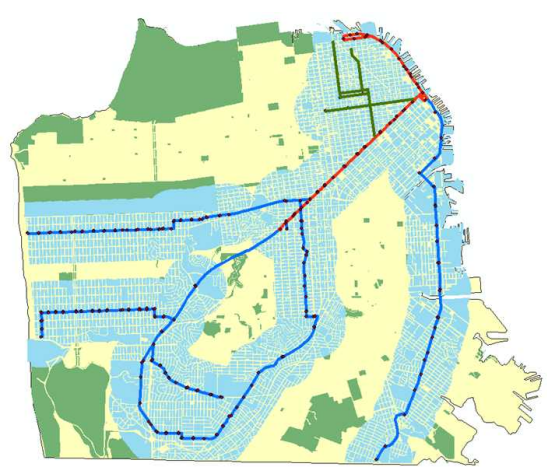

(b)

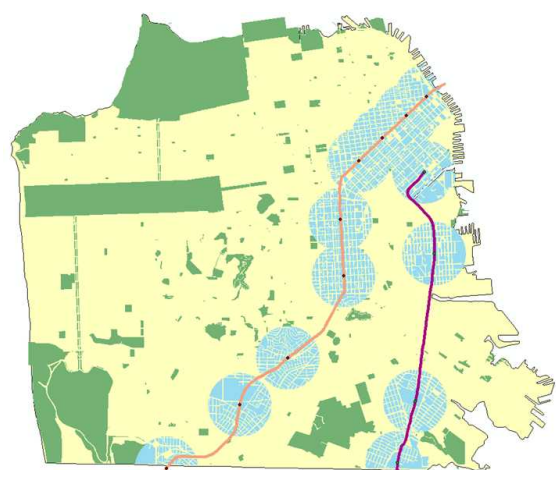

(c)

Figure 4. Public transit mapping (a) bus stops, (b) light rail stations, (c) commuter rail stations

Unlike the market value, the appraised value is not necessarily the price for which a property will be bought or sold. Rather, it is a guideline for the selling or buying process[22]. Generally, a property will not be sold for more than the appraised value, especially if a lender is financing the purchase. However, the property may, in reality, be worth more than the appraised value to a buyer and a seller.

Appraisal reports are also used for various purposes, such as insurance, home loans, tax loss, estates, liquidation and net worth. Therefore, this study focuses on the appraised value of land in order to investigate the economic impact of public transit on vacant land in San Francisco County.

\section{The Impact Analysis of LEED-NC PTA on Appraised Unit Value of Land}

\subsection{Sample Selection Methods}

In this study, in order to collect and manage data for statistical analysis, GIS files retrieved from several sources were used. With these data, the LEED-NC PTA map was created to form new data. The study area is defined as all parcels within San Francisco County. After identifying all parcels using the GIS tool, all unimproved parcels were selected, and these were approximately 4,800 parcels, as shown in Figure 3.

After mapping public transit as shown in Figure 4, the impact of LEED-NC PTA factors on qualified parcels for bus, light rail and commuter rail stations were examined as follows. First, the unimproved parcels within one-quarter mile of any bus stops were selected as shown in Figure 4 (a). Second, LEED-NC PTA qualified parcels with access to the light rail and commuter rail system, which are within a half-mile from stations, were selected as shown in Figure 4 (b) and (c), then the sample parcels were randomly selected for residential and mixed zones.

In this study, in residential zones, there were 2,539 unimproved parcels in September 2010[24]. Of these, 30\% (762 parcels) of the residential unimproved parcels were randomly selected. For mixed zone, the total number of unimproved parcels was 273, and 50\% (137 parcels) of these were randomly selected. In addition, an acceptability standard was applied to limit parcel selection to those parcels that were not less than the minimum allowed parcel size according to the zoning code.

Finally, the appraised land value (in dollars) and 
the land area of sample parcels were collected from the Office of the Assessor-Recorder from the City and County of San Francisco website[24].

\subsection{Descriptive Analysis}

Table 2 shows descriptive statistics of land value and parcel size for mixed and residential zones. The average parcel unit value of mixed zone is $\$ 119.47 /$ sqft for bus of qualified LEED-NC PTA, $\$ 142.62 /$ sqft for light rail, and $\$ 158.44 /$ sqft for commuter rail, which is higher than in the residential zone because most mixed parcels were located downtown. In addition, the average residential parcel size is 6,926.29 sqft for bus, 7,764.30 sqft for light rail and 7,243.85 sqft for commuter rail, which is higher than that of the mixed zone. Since downtown parcel sizes are smaller than those outside of downtown, residential zone parcel size is bigger than that of the mixed zone.

Table 2. Descriptive Statistics for land value and parcel size

\begin{tabular}{|c|c|c|c|c|c|c|c|c|}
\hline & \multicolumn{4}{|c|}{$\begin{array}{c}\text { Mixed } \\
\text { (137 parcel samples) }\end{array}$} & \multicolumn{4}{|c|}{$\begin{array}{c}\text { Residential } \\
\text { (762 parcel samples) }\end{array}$} \\
\hline & \multicolumn{2}{|c|}{ \$/sqft } & \multicolumn{2}{|c|}{$\begin{array}{c}\text { Parcel size } \\
(\text { sqft })\end{array}$} & \multicolumn{2}{|c|}{$\$ /$ sqft } & \multicolumn{2}{|c|}{$\begin{array}{c}\text { Parcel size } \\
\text { (sqft) }\end{array}$} \\
\hline & Mean & StDev & Mean & StDev & Mean & StDev & Mean & StDev \\
\hline $\begin{array}{l}\text { Bus } \\
\text { stop }\end{array}$ & 119.47 & 142.68 & $5,708.52$ & 5623.82 & 47.29 & 58.60 & $6,926.29$ & $25,605.8$ \\
\hline $\begin{array}{l}\text { Light } \\
\text { rail }\end{array}$ & 142.62 & 152.08 & $5,659.74$ & $6,136.78$ & 49.74 & 61.33 & $7,764.30$ & $28,757.0$ \\
\hline $\begin{array}{c}\text { Comm } \\
\text { uter } \\
\text { rail }\end{array}$ & 158.44 & 166.77 & $4,354.75$ & $1,903.05$ & 48.90 & 66.42 & $7,243.85$ & $30,049.9$ \\
\hline
\end{tabular}

\subsection{Correlation Analysis}

\subsubsection{Mixed zone}

Table 3 represents the Pearson's correlation results for mixed zone. As shown in Table 2, only $\mathrm{DR}_{\mathrm{m}}$ is not significantly correlated to $\mathrm{UV}_{\mathrm{m}}$. In detail, $\mathrm{NB}_{\mathrm{m}}, \mathrm{NL}_{\mathrm{m}}$, and $\mathrm{NR}_{\mathrm{m}}$ show a positive correlation to the dependent variable, $\mathrm{UV}_{\mathrm{m}}$. However, $\mathrm{DB}_{\mathrm{m}}$, and $\mathrm{DL}_{\mathrm{m}}$ show a negative correlation with $\mathrm{UV}_{\mathrm{m}}$. Therefore, the impact of variables on $\mathrm{UV}_{\mathrm{m}}$ indicates that the appraised unit value of a parcel increases as the number of LEED-NC qualified transit stops increases (bus, light rail, and commuter rail). In addition, the appraised unit value of a parcel increases as the distance to LEED-NC qualified bus stops and light rail stations from the parcel centroid decrease.

In terms of the correlation between variables, there is a positive relationship between $\mathrm{NB}_{\mathrm{m}}, \mathrm{NL}_{\mathrm{m}}$, and $\mathrm{NR}_{\mathrm{m}}$ which means that the number of bus stops within one-quarter mile distance increases as the number of light rail or commuter rail stations increases within a half-mile distance. Furthermore, $\mathrm{DB}_{\mathrm{m}}, \mathrm{DL}_{\mathrm{m}}$, and $\mathrm{DR}_{\mathrm{m}}$ have a positive relationship. In other words, when the distance from parcel centroid to bus stop is shorter, the distance from parcel centroid to light rail and commuter rail stations is also shorter.

With regard to parcel size, $\mathrm{NB}_{\mathrm{m}}, \mathrm{NL}_{\mathrm{m}}$, and $\mathrm{NR}_{\mathrm{m}}$ are negatively related to $A R E A_{m}$, which means that the number of bus stops, light rail and commuter rail stations decreases as parcel size increases. However, $\mathrm{DB}_{\mathrm{m}}, \mathrm{DLm}$, and $\mathrm{DR}_{\mathrm{m}}$ are positively related to $\mathrm{AREA}_{\mathrm{m}}$, which indicates that as parcel size increases, the distance from parcel centroid to transit stops also increases.

\subsubsection{Residential zone}

As shown in Table 4, for residential zone, five variables $\left(\mathrm{NB}_{\mathrm{r}}, \mathrm{NL}_{\mathrm{r}}, \mathrm{DB}_{\mathrm{r}}, \mathrm{DL} r\right.$, and $\left.\mathrm{AREA}_{\mathrm{r}}\right)$ are correlated to $\mathrm{UV}_{\mathrm{r}}$ at $\mathrm{p}\left\langle=0.05\right.$. In addition, $\mathrm{NB}_{\mathrm{r}}$, and $\mathrm{NL}_{\mathrm{r}}$ have a positive relationship to the $\mathrm{UV}_{\mathrm{r}}$, while $\mathrm{DB}_{\mathrm{r}}, \mathrm{DL}_{\mathrm{r}}$ and $\mathrm{AREA}_{\mathrm{r}}$ have a negative relationship. Specifically, the appraised unit value of a parcel increases as the number of LEED-NC qualified bus and light rail stations increases. Secondly, as the distance to LEED-NC qualified bus stops and light 
Table 3. Pearson's Correlation Results for Mixed Zone

\begin{tabular}{|c|c|c|c|c|c|c|c|c|}
\hline & $U V_{m}$ & $\mathrm{NB}_{\mathrm{m}}$ & $\mathrm{NLm}_{m}$ & $\mathrm{DB}_{\mathrm{m}}$ & $\mathrm{NR}_{\mathrm{m}}$ & $D L_{m}$ & $\mathrm{DR}_{\mathrm{m}}$ & $\mathrm{AREA}_{\mathrm{m}}$ \\
\hline \multicolumn{9}{|l|}{ Correlation } \\
\hline$U V_{m}$ & 1 & 0.682 & 0.507 & -0.450 & 0.378 & -0.371 & -0.172 & -0.092 \\
\hline $\mathrm{NB}_{\mathrm{m}}$ & 0.682 & 1 & 0.379 & -0.607 & 0.352 & -0.433 & -0.209 & -0.128 \\
\hline$N L_{m}$ & 0.507 & 0.379 & 1 & -0.331 & 0.455 & -0.651 & -0.206 & -0.027 \\
\hline $\mathrm{DB}_{\mathrm{m}}$ & -0.450 & -0.607 & -0.331 & 1 & -0.223 & 0.411 & 0.210 & 0.140 \\
\hline$D L_{m}$ & -0.371 & -0.433 & -0.651 & 0.411 & -0.390 & 1 & 0.495 & 0.029 \\
\hline $\mathrm{DR}_{\mathrm{m}}$ & -0.172 & -0.209 & -0.206 & 0.210 & -0.509 & 0.495 & 1 & 0.164 \\
\hline AREA $_{m}$ & -0.092 & -0.128 & -0.027 & 0.140 & -0.177 & 0.029 & 0.164 & 1 \\
\hline \multicolumn{9}{|l|}{ Sig (1-tailed) } \\
\hline$U V_{m}$ & & 0.000 & 0.000 & 0.000 & 0.000 & 0.000 & 0.069 & 0.047 \\
\hline$N L_{m}$ & 0.000 & 0.000 & & 0.000 & 0.000 & 0.000 & 0.011 & 0.383 \\
\hline $\mathrm{DB}_{\mathrm{m}}$ & 0.000 & 0.000 & 0.000 & & 0.007 & 0.000 & 0.010 & 0.062 \\
\hline $\mathrm{NR}_{\mathrm{m}}$ & 0.000 & 0.000 & 0.000 & 0.007 & & 0.000 & 0.000 & 0.025 \\
\hline $\mathrm{DL}_{\mathrm{m}}$ & 0.000 & 0.000 & 0.000 & 0.000 & 0.000 & & 0.000 & 0.376 \\
\hline $\mathrm{DR}_{\mathrm{m}}$ & 0.069 & 0.010 & 0.011 & 0.010 & 0.000 & 0.000 & & 0.035 \\
\hline AREA $_{m}$ & 0.047 & 0.070 & 0.383 & 0.062 & 0.025 & 0.376 & 0.035 & \\
\hline \multicolumn{9}{|c|}{$\begin{array}{l}\mathrm{UV}_{\mathrm{m}} \text { : Appraised unit value of unimproved parcel for mixed zone } \\
\mathrm{NB}_{\mathrm{m}} \text { : Number of bus stops within one-quarter mile from the parcel centroid } \\
\mathrm{NL}_{\mathrm{m}} \text { : Number of light rail stations with in half mile from the parcel centroid } \\
\mathrm{NR}_{\mathrm{m}} \text { : Number of rail stations within half mile from the parcel centroid }\end{array}$} \\
\hline
\end{tabular}

Table 4. Pearson's Correlation Results for Residential Zone

\begin{tabular}{|c|c|c|c|c|c|c|c|c|}
\hline & $U V_{r}$ & $\mathrm{NB}_{\mathrm{r}}$ & $\mathrm{NL} r$ & $\mathrm{DB}_{\mathrm{r}}$ & $\mathrm{NR}_{\mathrm{r}}$ & DLr & $\overline{D R_{r}}$ & $\mathrm{AREA}_{\mathrm{r}}$ \\
\hline \multicolumn{9}{|l|}{ Correlation } \\
\hline$U V_{r}$ & 1 & 0.706 & 0.612 & -0.340 & -0.118 & 0.081 & -0.078 & -0.042 \\
\hline$N L_{r}$ & 0.612 & 0.473 & 1 & -0.282 & -0.617 & 0.028 & -0.122 & -0.036 \\
\hline $\mathrm{DB}_{\mathrm{r}}$ & -0.340 & -0.616 & -0.282 & 1 & 0.272 & -0.118 & 0.374 & 0.041 \\
\hline $\mathrm{DL} r$ & 0.081 & 0.072 & 0.028 & -0.118 & -0.145 & 1 & -0.548 & -0.005 \\
\hline $\mathrm{DR}_{\mathrm{r}}$ & -0.078 & -0.194 & -0.122 & 0.374 & 0.394 & -0.548 & 1 & -0.012 \\
\hline AREAr & -0.042 & -0.011 & -0.036 & 0.041 & 0.011 & -0.005 & -0.012 & 1 \\
\hline \multicolumn{9}{|c|}{ Sig (1-tailed) } \\
\hline$U V_{r}$ & & 0.000 & 0.000 & 0.000 & 0.019 & 0.077 & 0.085 & 0.037 \\
\hline$N L_{r}$ & 0.000 & 0.000 & & 0.000 & 0.000 & 0.314 & 0.016 & 0.064 \\
\hline $\mathrm{DB}_{\mathrm{r}}$ & 0.000 & 0.000 & 0.000 & & 0.000 & 0.019 & 0.000 & 0.037 \\
\hline $\mathrm{NR}_{\mathrm{r}}$ & 0.019 & 0.002 & 0.000 & 0.000 & & 0.005 & 0.000 & 0.024 \\
\hline $\mathrm{DL}_{\mathrm{r}}$ & 0.077 & 0.105 & 0.314 & 0.019 & 0.005 & & 0.000 & 0.068 \\
\hline $\mathrm{DR}_{\mathrm{r}}$ & 0.085 & 0.000 & 0.016 & 0.000 & 0.000 & 0.000 & & 0.016 \\
\hline AREA $_{r}$ & 0.037 & 0.023 & 0.064 & 0.037 & 0.024 & 0.068 & 0.016 & \\
\hline
\end{tabular}

$\mathrm{UV}_{\mathrm{r}}$ : Appraised unit value of unimproved parcel for residential zone

$\mathrm{DB}_{\mathrm{r}}$ : Closest distance from the parcel centroid to bus stop

$\mathrm{NB}_{\mathrm{r}}$ : Number of bus stops within one-quarter mile from the parcel centroid

$\mathrm{DL}_{\mathrm{r}}$ : Closest distance from the parcel centroid to light rail station

$\mathrm{NL}_{\mathrm{r}}$ : Number of light rail stations with in half mile from the parcel centroid

$\mathrm{DR}_{\mathrm{r}}$ : Closest distance from the parcel centroid to rail station

$\mathrm{NR}_{\mathrm{r}}$ : Number of rail stations within half mile from the parcel centroid

AREA : parcel size (sqft) 
rail station from parcel centroid decreases, the appraised unit value of the parcel increases.

The correlation between variables $\mathrm{NB}_{\mathrm{r}}$ and $\mathrm{NL}_{\mathrm{r}}$ has a positive relationship, which means that as the number of bus stops within one-quarter mile distance from the parcel centroid increases, the number of light rail stations within a half-mile distance also increases. In addition, $\mathrm{DB}_{\mathrm{r}}, \mathrm{DL}_{\mathrm{r}}$, and $\mathrm{DR}_{\mathrm{r}}$ have a positive relationship, which means that when the distance from parcel centroid to bus stop is shorter, the distance from parcel centroid to light rail and commuter rail stations is also shorter.

$\mathrm{NB}_{\mathrm{r}}$ is negatively related to $\mathrm{AREA}_{\mathrm{r}}$. In detail, the number of bus stops decreases as the parcel size increases. However, $\mathrm{DB}_{\mathrm{r}}, \mathrm{DL}_{\mathrm{r}}$, and $\mathrm{DR}_{\mathrm{r}}$ are positively related to AREA. This indicates that as the distance from parcel centroid to transit stops (bus, light rail, and commuter rail) increases, the parcel size increases.

\section{Discussion}

Pearson's correlation analysis was performed to examine the relationships between appraised unit value of land and LEED-NC PTA qualified parcels. First, the correlation between appraised unit value of parcel and number of bus stops within one-quarter mile distance was checked. In both mixed and residential zones, this shows a positive relationship, but this is stronger in residential zones. In other words, the appraised unit value of parcels is more highly related to the number of bus stops in residential zones than in mixed zones. As the number of bus stops increases, the appraised land value also increases.

In addition, the correlation between appraised unit value of a parcel and distance from parcel centroid to the nearest bus stop represents a negative relationship. In other words, the appraised land value increases as the distance to a LEED-NC qualified bus stops decreases. This negative relationship is stronger in mixed zones than in residential zones, which means that the appraised land value becomes higher than it is in residential zones as the distance to bus stops decreases.

Second, the correlation between appraised unit value of parcel and number of light rail stations within one half-mile distance shows a positive relationship. In other words, the appraised land value increases as the number of light rail stations increases, both in residential and in mixed zones. Furthermore, in mixed zones, the relationship between appraised unit value of parcel and closest distance from parcel centroid to a light rail station represents a negative relationship. As the distance to a light rail station decreases, the appraised land value is increased. But in residential zones, this relationship was not shown.

Third, considering proximity to a commuter rail system, only mixed zones showed a positive relationship between appraised unit value of parcel and the number of commuter rail stations within one half-mile distance. For residential zones, proximity to a commuter rail system is not related to appraised unit value of parcel.

\section{Conclusions}

According to the correlation results, for mixed zone, the appraised unit value of parcel increases as the number of LEED-NC qualified transit stops increases (bus, light rail, and commuter rail). In addition, the appraised value increases as the distance to LEED-NC qualified bus stops and light rail stops decreases. For residential zones, the appraised unit value of parcel increases as the 
number of LEED-NC qualified bus and light rail stations increases. Furthermore, the appraised unit value of parcel increases as the distance to LEED-NC qualified bus stops decreases.

This study proved that there are significant relationships between the appraised unit value of parcels in San Francisco County and the LEED-NC PTA criteria. Many land developers still believe that sustainable development may impose additional costs and durations. However, this study concludes that LEED-NC PTA qualified parcels have significantly higher land values. This conclusion demonstrates the economic benefits of adopting the LEED-NC PTA criteria, indicating that adopting LEED-NC has economic benefits in the long term. The findings of this study could encourage real-estate developers to site their projects according to the LEED-NC PTA criteria. In addition, the LEED-NC PTA map procedures using GIS can be applied to other cities to analyze the appraised unit value of land.

\section{Acknowledgement}

This work was supported by the National Research Foundation of Korea (NRF) grant funded by the Korea government (MEST) (No. 2012-0000609).

\section{References}

1. Gonchar J. Rapidly Evolving Rating System Draws Applause and Criticism. Engineering News-Record. 2005 Feb;254(8):18.

2. U.S. Green Building Council (USGBC), LEED for New Construction \& Major Renovation [Internet]. Washington D.C.: U.S Green Building Council(USGBC); 2008 November [cited 2011 November 21]. Available from: http://www.usgbc.org/ShowFile.aspx?DocumentID=5546

3. U.S. Green Building Council (USGBC), LEED Version 3.0 [Internet]. Washington D.C.: U.S Green Building
Council(USGBC); 2009 April [cited 2011 November 30]. Available from: https://www.leedonline.com/

4. U.S. Green Building Council (USGBC). What LEED is? [Internet]. Washington D.C.: U.S Green Building Council(USGBC); 2011 April [cited 2011 October 11]. Available from: http://www.usgbc.org/DisplayPage.aspx?CMSPageID=19887

5. Rahman F, Sadeghpour F. Canadian Industry Practitioners Perception on LEED Credits, Report, Construction Research Congress 2010. Innovation for Reshaping Construction Practice. 2010 May:2:1547-55.

6. Kibert CJ. Sustainable Construction -Green Building Design and Delivery. New York( NY): John Wiley \& Sons; 2005. 432 p.

7. San Francisco Municipal Transportation Agency (SFMTA). Routes and Schedules [Internet]. San Francisco: Demand Media: SFGate; 2011 Oct [cited 2011 February 3]. Available from: http://www.sfta.com/cms/mroutes/indxrout.html

8. Lutzenhiser M, Netusil NR. The effect of open spaces on a home's sale price. Contemporary Economic Policy. 2001;19(3):291-8

9. Schultz SD, King DA. The use of census data for hedonic price estimates of open-space amenities and land use Journal of Real Estate Finance and Economics, 2001;22(3):239-52.

10. Baranzini A, Schaerer C. A sight for sore eyes: Assessing the value of view and land use in the housing market. Journal of Housing Economics. 2011;20:191-9.

11. Cervero R, Duncan M. Land Value Impact of Rail Transit Services in Los Angeles County, National Association of Realtors Urban Land Institute. Washington (WA): Urban Land Institute; 2002. 37 p.

12. Landis J, Guhathakurta S, Zhang M. Capitalization of Transit Investments into Single-Family Home Prices, California (CA): University of California Transportation Center; 1994. 38 p.

13. Gatzlaff D, Smith M. The impact of the Miami Metrorail on the value of residences near station locations. Land Economics. 1993;69(4):54-66.

14. Benson ED, Hansen JL, Schwartz Jr. AL, Smersh GT. Pricing residential amenities: the value of a view. Journal of Real Estate Finance and Economics. 1998;16(1):55-73.

15. Geoghegan J. The value of open spaces in residential land use. Land Use Policy. 2002;19(1):91-8.

16. Irwin GE. The effects of open space on residential property 
values. Land Economics. 2002;78(4):465-80.

17. Seiler MJ, Bond T, Seiler VL. The impact of world class great lakes water views on residential property values. Appraisal Journal. 2001;69:287-95.

18. Yu SM, Han SS, Chai CH. Modeling the value of view in real estate valuation: a3-DGIS approach. Environment and Planning B: Planning and Design. 2007;34;139-53.

19. Park YJ. Predicting the Unit Appraisal Value of the Unimproved and Private Land in the City of Houst on by LEED Sustainable Site Criteria [Dissertation]. Texas (TX): Texas A\&M University; 2009. 102 p.

20. Joshi B. Prediction of Unit Value of Un-Improved Parcels of Harris County, Texas Using LEED Sustainable Sites Criteria of Public Transportation Access [Master's Thesis]. Texas (TX): Texas A\&M University; 2009. 88 p.

21. Castro LT. Market Value vs. Appraised Value [Internet]. San Francisco: Demand Media: SFGate; 2011 Oct [cited 2011 November 21]. Available from: http://homeguides.sfgate. com/market-value-vs-appraised -value-1206.html

22. Guerra T. Assessed Value vs. Appraised Value of Home [Internet]. San Francisco: Demand Media: SFGate; 2011 Oct [cited 2011 November 21]. Available from: http:// homeguides.sfgate.com/assessed-value-vs-appraised-value -home-6873.html

23. Bramble L. How Do I Raise the appraisal value of a home [Internet]. San Francisco: Demand Media: SFGate; 2011 Oct [cited 2011 November 21]. Available from: http:// homeguides.sfgate.com/raise-appraisal-value-home-remod eling-1296.html

24. California Spatial Information Library, state public data. Geospatial Crearinghouse. [Internet]. California [cited 2011 April 18]. Available from: http://www.atlas.ca.gov/ download.html 